\title{
The 1986 College Library Standards: Application and Utilization David B. Walch
}

There have been several iterations of college library standards and guidelines since the 1920s. The 1986 College Library Standards, written by an Association of College and Research Libraries' committee, were to address developing concerns in academic libraries. These concerns include collections and staff formulae, budget, audiovisual collections and services, networking, and cooperative associations. This article provides a comparison between the 1975 and 1986 editions of the College Library Standards and summarizes the changes made. It also analyzes the results of a survey of 215 academic libraries. The purpose of the survey was to determine the use and effectiveness of the standards. The results show that the standards are widely used, and that there is keen interest in the application and further development of the standards. Specific recommendations for changes are made.

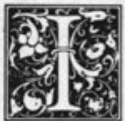

n 1982, an ad hoc committee was appointed by the Association of College and Research Libraries (ACRL) to review the 1975 edition of The College Library Standards. The committee was charged "to recommend revision which would bring them up to date and make them more generally useful."' Particular concern was expressed about the currentness of the collection formula (Formula A), staff formula (Formula B), and the budget standard (6 percent of the institution's general budget). Matters relating to nonprint collections and services, as well as networking and cooperative associations which had not been included in the 1975 standards, also needed to be addressed. ${ }^{2}$ From 1982 until the publication of the 1986 standards, the ad hoc committee worked to meet its charge to review and revise each standard in light of developing technology, networking, resource sharing, and audiovisual materials.

\section{A COMPARISON OF} THE 1975 AND 1986 STANDARDS

Although few substantial changes were made in the 1986 standards, many commonalities remained between the two. The same number of standards were enumerated in the same order, and they remained quantitative in nature. The formula concept for determining adequacy of collection, staff, and size of library was left intact, although some formula ingredients changed. A review of the major changes and differences is highlighted below:

- Standard 1: Objectives. No major changes.

- Standard 2: Collections. A major difference between the two editions of the standards was in what was to be counted in Formula A as volumes. The 1975 standards included only print and microform volume equivalents as items to be counted. The 1986 standards allowed books and microforms,

David B. Walch is Dean of Library Services at California Polytechnic State University, San Luis Obispo, California 93407. 
as well as videocassettes, films, videodiscs, sound recordings, filmstrips, loops, slide-tape sets, graphic materials (including maps), computer software, and slides. Also, the 1986 standards permitted libraries to count the number of items borrowed through interlibrary loan or through other resource-sharing arrangements.

- Standard 3: Organization of Materials. Slight modifications were made in Formula 3. The 1975 standards stated, "The catalog may be developed either by a single library or jointly among several libraries." This was omitted entirely in the 1986 edition. The 1975 standards also stated, "Patrons shall have direct access to library materials on the shelives." Though this portion of the standard was omitted, the 1986 standards did state that materials placed in storage facilities "shall be readily accessible to users." The change was made because some academic libraries were having to cope with off-site storage.

- Standard 4: Staff. The 1986 standards were somewhat more explicit in stating as part of Standard 4.4, "The support staff shall be no less than $65 \%$ of the total library staff, not including student assistants." On the same issue, the 1975 standards state that "librarians will seldom comprise more than 25$35 \%$ of the total Full Time Equivalent (FTE) library staff." The 1986 standards also added an extensive list of "Supplementary Staffing Factors to Be Considered," including hours of service, computer-based services, audiovisual services, and size and configuration of facilities.

- Standard 5: Service. A 1975 standard that referred specifically to "the provision of inexpensive means of photocopying" was omitted from the 1986 standards because photocopy service is a universal service currently provided in nearly all academic libraries. The 1986 standards also included a separate standard related to cooperative programs. In the 1975 version, this was incorporated into the interlibrary loan standard.
- Standard 6: Facilities. There was a minor modification in Formula C. The 1975 version recommended 25 square feet per study station and one-fourth of the sum of the space needed for readers and books dedicated to office, operational, and equipment activities. The 1986 version recommended 25 to 35 square feet per study station and one-eighth of the sum of the space needed for readers and books dedicated for office, operational, and equipment activities.

- Standard 7: Administration. The 1986 standards omitted two standards that were included in the 1975 version. One referred to keeping statistics for purposes of planning and information, and the other dealt with the need to seek out and utilize cooperative programs.

- Standard 8: Budget. The major change in the 1986 standards was a separate standard addressing the need for budget augmentation if the library has responsibility for "acquiring, processing, and servicing audiovisual materials and microcomputer resources." 3

In summary, the changes between the 1975 and 1986 standards were slight. They included the opportunity to count all types of audiovisual materials plus items borrowed through interlibrary loan in Formula A; a recognition of offsite storage; allowance for an increase in the square feet per library study stations; a decrease in the amount of space assigned for office/operational activities and equipment; and a recognition of the need to increase the budget if the library is responsible for audiovisual and microcomputer services.

\section{SURVEY METHODOLOGY}

Because these changes were made, the committee wanted to determine if the 1986 standards were meeting the needs of those whom they were designed to serve, such as institutions defined by the Carnegie Commission on Higher Education as Liberal Arts Colleges I and II and Comprehensive Universities and Colleges I and II. ${ }^{4}$ In order to determine this, a survey of institutions from these classi- 
TABLE 1

FACULTY : LIBRARIAN RATIO

\begin{tabular}{lccc}
\hline & $\begin{array}{c}\text { FTE } \\
\text { Faculty }\end{array}$ & $\begin{array}{c}\text { FTE } \\
\text { Librarian }\end{array}$ & Ratio \\
\hline Carnegie I comprehensive public & 19,291 & 691.9 & $27.9: 1$ \\
Carnegie I comprehensive private & 3,406 & 129.8 & $26.2: 1$ \\
Carnegie I liberal arts private & $2,822.4$ & 153.3 & $18.4: 1$ \\
Total Carnegie I & $25,519.4$ & 975 & $26.2: 1$ \\
Carnegie II comprehensive public & 1,258 & 51.3 & $24.5: 1$ \\
Carnegie II comprehensive private & 2,027 & 91.1 & $22.3: 1$ \\
Carnegie II liberal arts private & 2,630 & 127.5 & $20.6: 1$ \\
Carnegie II liberal arts public & 379 & 18.5 & $20.5: 1$ \\
Total Carnegie II & 6,294 & 288.4 & $21.8: 1$ \\
Total-all institutions & $31,813.4$ & $1,263.4$ & $25.2: 1$ \\
\hline
\end{tabular}

fications was made. The survey was prepared and reviewed by members of the Standards Committee of the College Library Section of ACRL. The committee consisted of Lynne Chmelir, Rebecca Dixon, Claudette Hagle, Diana Parker, and David B. Walch.

The survey was sent to twenty-one institutions for pretesting. This process resulted in some minor modifications. The survey was then submitted to the ACRL office for review, and that, too, resulted in minor changes. The final version of the eight-page questionnaire was distributed to 236 level I institutions and 200 level II liberal arts and comprehension institutions. Two hundred and fifteen questionnaires were returned, making for a response rate of 41.8 percent. In many respects, the survey parallels one that was done by a College Libraries Section Committee in 1979 and that was reported on by Larry Hardesty and Stella Bentley. The committee conducted a survey of 300 institutions on the use and effectiveness of the 1975 standards. The results were reported in the ACRL's Second National Conference of $1987 . .^{5}$

\section{SURVEY RESULTS}

The initial part of the survey sought demographic data, such as student enrollment, faculty size, number of librarians and library support staff, and number of majors offered at the bachelor's, master's, and Ph.D. levels. The survey also sought responses regarding the various units reporting to the chief library administrator, including audiovisual services, academic computing, and computing labs. Other data collected related to number of volumes (print, microform, and nonprint), operating expenditures, and annual growth of the book collection. Below is a summary of information gleaned from responses to the survey.

\section{Ratio of Librarians to Faculty}

Standard 4 and Formula B specifically address standards related to library staff, and are considered later. However, because Formula B is based only on enrollment, collection size, and growth of the collection, it is of interest to know the ratio of librarians to faculty. To the author's knowledge, this ratio has not been available, except for select library groups that collect their own data, such as the Association of Research Libraries (see table 1).

\section{External Units Reporting to Library Administration}

Over the past several years, more and more library directors have been given administrative responsibility for activities not normally incorporated within the traditional library. Chief among these activities are audiovisual units. A previous study of sixty randomly selected academic institutions showed 
TABLE 2

UNITS REPORTING TO LIBRARY ADMINISTRATORS

\begin{tabular}{lcccc}
\hline & Audiovisual & Archives & Ac Comp. & Comp. Labs \\
\hline Carnegie I comprehensive public & 31 & 24 & 0 & 5 \\
Carnegie I comprehensive private & 10 & 16 & 0 & 0 \\
Carnegie I liberal arts private & 13 & 17 & 2 & 1 \\
Carnegie II comprehensive public & 8 & 8 & 2 & 5 \\
Carnegie II comprehensive private & 9 & 12 & 0 & 0 \\
Carnegie II liberal arts private & 33 & 31 & 4 & 6 \\
Carnegie II liberal arts public & 2 & 3 & 1 & 0 \\
Total & 106 & 111 & 9 & 17 \\
Percent & 49.3 & 51.6 & 4 & 7.9 \\
\hline
\end{tabular}

TABLE 3

KNOWLEDGE AND USE OF THE 1985 STANDARDS

\begin{tabular}{lc}
\hline Knowledge of Standards & $\%$ \\
\hline $\begin{array}{l}\text { Thoroughly familiar } \\
\text { with details }\end{array}$ & 18.9 \\
$\begin{array}{l}\text { Very familiar with general } \\
\text { context }\end{array}$ & 39.3 \\
Familiar in general & 34.0 \\
Aware but not familiar & 7.3 \\
Not familiar at all & 0.5 \\
\hline
\end{tabular}

Use of Standards

To justify improvement to

10.2 physical plant

To justify library budget

To justify staff expansion

To justify collection upgrade

To justify improvement of services in general

To prepare accreditation and/ or institutional self studies

To orient/educate college administration

Have not used

Other

that 33 percent of audiovisual directors reported to a library administrator. ${ }^{6}$ This survey of 215 institutions showed a somewhat higher percentage (see table 2). The survey also made it clear that there has not been a rush to merge aca- demic computing activities administratively with the library. Also noted is the small percentage of libraries that have and are responsible for computer labs.

\section{Knowledge and Use of the 1986 Standards}

The Hardesty/Bentley survey revealed that 61.6 percent of the respondents were either "very" or "thoroughly" familiar with the 1975 standards. The survey of the 1986 standards showed a nearly identical trend, with 58.2 percent being "very" or "thoroughly" familiar. Table 3 also shows that the three major uses of the standards related to accreditation, arguing for budget augmentation, and education of college administrators. This contrasts sharply with the Hardesty/Bentley survey, which indicated that the greatest use of the 1975 standards was to upgrade the collections and to improve services. It should be noted that, in general, more use is made of the standards by the smaller institutions, such as Carnegie Type II, than by the larger schools. The directors of the smaller institutions have more knowledge of the standards than do their counterparts on the larger campuses.

\section{Standard 2: Collections}

In an attempt to recognize the increasing growth and utilization of audiovisual material and microforms, the 1986 standards included a count of these types of materials within the collection 
TABLE 4A

FORMULA A-COLLECTION

\begin{tabular}{lccccc}
\hline & Too High & & Adequate & & Too Low \\
\cline { 2 - 6 } & 5 & 4 & 3 & 2 & 1 \\
\hline $\begin{array}{c}\text { Survey of 1975 Standards (No Audiovisual } \\
\text { or Interlibrary Loan)* }\end{array}$ & $9.9 \%$ & $16.5 \%$ & $46.2 \%$ & $9.9 \%$ & $8.2 \%$ \\
$\begin{array}{c}\text { Survey of 1986 Standards (includes } \\
\text { Audiovisual and Interlibrary Loan) }\end{array}$ & $7.7 \%$ & $10.8 \%$ & $45.9 \%$ & $16.0 \%$ & $19.6 \%$ \\
\hline
\end{tabular}

* Percentages in 1975 do not equal 100 percent since that survey also included a percent for "no opinion" ( 3.8 percent) and "no response" (5.5 percent)

TABLE 4B

1986 FORMULA A-"GRADED" COLLECTION SIZE

$66.0 \%$-Grade A

$18.2 \%$-Grade B

9.4\%-Grade C

$6.4 \%-$ Grade D
(90-100\% of volumes called for in Formula A)

(75-89\% of volumes called for in Formula A)

(60-74\% of volumes called for in Formula A)

( $0-59 \%$ of volumes called for in Formula A) formula, such as Formula A. The standards also provided a means for items borrowed through interlibrary loan and other resource-sharing arrangements to be counted in Formula A. Standard 2.2 stated that "audiovisual holdings may be counted as bibliographic unit equivalents and this number should be added to that for print volumes and volume equivalents in measuring a library's collection against Formula A."7 The standard then provided "bibliographic unit equivalents" for various audiovisual formats. For example, one videocassette or fifty slides equals one bue. Microform holdings were also counted in the formula with one microfilm reel, or ten pieces of any other microform, equaling one volume.

The allowance made for adding audiovisual items to the formula count caused some respondents to consider the formula requirements as too low. For example, one library director observed that "the number of audiovisual materials, maps, microforms, etc., give the collection an inflated rating." This may be a contributing factor to the data in table $4 \mathrm{~A}$, which compares responses to the Hardesty/Bentley survey of the 1975 standards to those of the current survey. While the percentage finding the formula "adequate" was nearly the same, the per- centage of those finding the 1986 formula "too low" was double that of the respondents to the 1975 formula. Table 4B further reflects this by showing that twothirds of all the institutions surveyed have "Grade A" collections. For instance, they have 90 to 100 percent of the holdings required by formula (see tables $4 \mathrm{~A}$ and 4B).

\section{Standard 4.3: Staffing Formula}

The same staffing formula is used in both versions. The recommendation that the support staff compose "not less than 65 percent of the total library staff" was also similar to the 1975 statement that "librarians will seldom comprise more than 25-35\% of the total FTE library staff." ${ }^{17}$ As noted in table $5 \mathrm{~A}$, the majority of the respondents to the 1986 and the 1975 standards surveys deemed the standard as adequate. Table 5B suggests that academic libraries find it far more difficult to meet the standard for staffing than the standard for book collections. For instance, only 33 percent meet the Grade A level for staff, while 66 percent achieve that same grade for book collection size. Table $5 \mathrm{C}$ also notes that more than 70 percent of the academic libraries do not meet the 65 percent recommended level of support staff (see tables $5 \mathrm{~A}, 5 \mathrm{~B}$, and $5 \mathrm{C}$ ). 
TABLE 5A

FORMULA B - STAFF

\begin{tabular}{lccccc}
\hline & Too High & \multicolumn{3}{c}{ Adequate } & \multicolumn{2}{c}{ Too Low } \\
\cline { 2 - 6 } & 5 & 4 & 3 & 2 & 1 \\
\hline Survey of 1975 standards & $10.4 \%$ & $15.4 \%$ & $52.2 \%$ & $10.4 \%$ & $6.6 \%$ \\
Survey of 1986 standards & $7.4 \%$ & $18.7 \%$ & $53.2 \%$ & $12.3 \%$ & $8.4 \%$ \\
\hline
\end{tabular}

* Percentages in 1975 do not equal 100 percent since that survey also included a percent for "no opinion" ( 0.5 percent) and "no response" ( 4.4 percent).

TABLE 5B

1986 FORMULA B - "GRADED" STAFF SIZE

\begin{tabular}{ll}
\hline $33.0 \%-$ Grade A & $(90-100 \%$ of staff called for in Formula B) \\
$21.9 \%-$ Grade B & $(75-84 \%$ of staff called for in Formula B) \\
$25.2 \%-$ Grade C & $(60-74 \%$ of staff called for in Formula B) \\
$19.9 \%-$ Grade D & $(50-54 \%$ of staff called for in Formula B) \\
\hline
\end{tabular}

TABLE 5 C

\section{SIZE OF SUPPORT STAFF}

$21.1 \%$ have $65 \%$ or more of staff in support staff positions.

$19.7 \%$ have $60-64 \%$ of staff in support staff positions.

$19.2 \%$ have $55-59 \%$ of staff in support staff positions.

$14.8 \%$ have $50-54 \%$ of staff in support staff positions.

$18.2 \%$ have $0-49 \%$ of staff in support staff positions.

\section{Standard 6.1: Space Formula}

The major change in Formula $\mathrm{C}$, which is the facilities formula, dealt with the space required for staff. In 1975 the formula recommended that the space required for such administrative purposes as staff offices, work areas, catalogs, files, and equipment equal one-fourth of the sum of the space required for readers and books. The 1986 standards recommend that only one-eighth of the sum of the space required for readers and books be devoted to administrative purposes. Both formulas noted that the space required for audiovisual purposes should be added to the calculations. The 1986 space formula also specified that space required for microforms, bibliographic instruction, and equipment and services associated with library technology also be added to the formula. The major ingredients of the formula, such as the allocation of space for readers and books, remained primarily the same. Table $6 \mathrm{~A}$ compares the 1975 response to that of 1986. Table 6B indicates the grade achieved by academic libraries as measured against Formula $C$ (see tables $6 \mathrm{~A}$ and $6 \mathrm{~B})$.

\section{Usefulness of the Standards}

Although some standards were deemed more useful than others, each of them received high marks for their value as a standard. Standard 2 (collections) was seen as being most useful when considering the high end of the "usefulness" scale. Standard 8 (budget) was considered the next most useful. Both of these standards have specific quantitative ingredients. The survey of the 1975 standards also showed Standard 2 to be the most useful, followed by Standard 7 (administration). Standard 3 (organization) was deemed the least useful in both surveys. Table 7 shows the response to the questions regarding usefulness (see table 7).

\section{Related Concerns}

The survey also suggested five additional areas for potential development of standards. These five areas included performance measures, database access, resource sharing, microcomputers, and 
TABLE 6A

FORMULA C - SPACE

\begin{tabular}{lccccc}
\hline & Too High & \multicolumn{2}{c}{ Adequate } & \multicolumn{2}{c}{ Too Low } \\
\cline { 2 - 6 } & 5 & 4 & 3 & \multicolumn{1}{c}{2} & \multicolumn{1}{c}{1} \\
\hline Survey of 1975 standards & $5.5 \%$ & $7.7 \%$ & $65.9 \%$ & $6.6 \%$ & $4.4 \%$ \\
Survey of 1986 standards & $.5 \%$ & $7.2 \%$ & $69.7 \%$ & $16.4 \%$ & $6.2 \%$ \\
\hline
\end{tabular}

* Percentages in 1975 do not equal 100 percent since that survey also included a percent for "no opinion" ( 8.8 percent) and "no response" (1.1 percent).

TABLE 6B

1986 FORMULA C"GRADED" SPACE

$49.5 \%=$ Grade $A(90-100 \%$ of the net assignable area called for by the formula).

$19.1 \%=$ Grade B $(75-89 \%$ of the net assignable area called for by the formula).

$21.1 \%=$ Grade C $(60-74 \%$ of the net assignable area called for by the formula).

$10.3 \%=$ Grade D $(50-59 \%$ of the net assignable area called for by the formula).

online catalogs. As noted in table 8, the majority of those responding indicated the development of standards for database access and resource sharing would be most useful (see table 8 ).

Directors also recommended as many as fifteen other areas, from document delivery to hours, that needed to be considered for inclusion within the standards. The audiovisual services area was mentioned the most. Although the initial charge given to the 1982 ad hoc committee specifically mentioned the need for addressing audiovisual concerns, the perception among some respondents was that more needs to be done. One of the difficulties the committee faced in its consideration was the paucity of audiovisual research needed to provide sufficient rationale that supports the quantitative measures that characterize the standards.

A final question on the survey asked which type of standard-quantitative or qualitative-best meets the needs of the profession. It is interesting to note that the 1979 university library standards reflected a qualitative nature. The foreward to the 1989 standards, however, states, "By far the most important of these [issues discussed by the committee responsible for the 1979 standards], was the question of whether standards should be quantitative or qualitative. In the end we concluded that neither approach was appropriate." ${ }^{\prime 9}$ Similar discussions were held by the committee that developed the 1986 standards. The decision in that instance was to continue with a quantitative approach. An overwhelming majority ( 64.5 percent) of the survey respondents expressed the desire to retain a quantitative approach; 25.6 percent favored a qualitative style; and

TABLE 7

USEFULNESS OF EACH STANDARD

\begin{tabular}{lccccc}
\hline & Useful & \multicolumn{3}{c}{ Modestly Useful } & Useless \\
\cline { 2 - 6 } Standard & 5 & 4 & 3 & 2 & 1 \\
\hline 1-Objective & 29.4 & 31.6 & 30.5 & 6.9 & 1.6 \\
2-Collection & 36.7 & 35.7 & 20.1 & 6.0 & 1.5 \\
3-Organization & 21.4 & 30.0 & 39.0 & 6.9 & 2.7 \\
4-Staff & 34.9 & 32.8 & 22.7 & 8.6 & 1.0 \\
5- Service & 30.2 & 36.4 & 24.0 & 7.3 & 2.1 \\
6- Facilities & 34.0 & 35.1 & 20.9 & 6.8 & 3.2 \\
7- Administration & 28.0 & 33.3 & 28.6 & 6.9 & 3.2 \\
8- Budget & 33.3 & 37.0 & 23.8 & 4.8 & 1.1 \\
\hline
\end{tabular}


TABLE 8

PRIORITY FOR FUTURE DEVELOPMENT OF STANDARDS

\begin{tabular}{lccccc}
\hline & High & \multicolumn{3}{c}{ Medium } & Low \\
\cline { 2 - 6 } Standard & 5 & 4 & 3 & 2 & 1 \\
\hline Performance measures & 27.3 & 32.8 & 25.2 & 10.1 & 4.6 \\
Database access & 34.7 & 35.7 & 23.6 & 3.0 & 3.0 \\
Resource sharing & 34.8 & 36.3 & 18.9 & 8.5 & 1.5 \\
Microcomputer & 20.9 & 31.6 & 32.2 & 8.7 & 6.6 \\
Online catalogs & 35.5 & 30.0 & 25.5 & 6.0 & 3.0 \\
\hline
\end{tabular}

9.9 percent said they would like to see the incorporation of both.

\section{REMAINING ISSUES}

The 1986 edition of the College Library Standards is in its seventh year. The survey showed that as many as 95 percent of the respondents found the standards to be "useful" to "very useful." Because of such a high rate of use, it is important that the standards remain current and viable. The results of the survey discussed here, plus the limited number of articles found in the literature relating to the 1986 standards, point to some areas that, at the very least, need tweaking and in some instances require fresh thought and approach. These areas are summarized below.

\section{Rationale for Quantitative Measures}

As previously noted, a substantial number of respondents favored the quantitative nature of the standards. However, current research and rationale to support the quantitative criteria are lacking. If such specificity is going to be articulated, then there needs to be current supporting documented research. The quantitative measures that need rationale include:

- Standard 2.2, Formula A (collection size).

- Standard 4.3, Formula B (staff size and composition).

- Standard 6.1, Formula C (library building).

- Standard 8.1, library budget.

One library director, Hans E. Bynagle, succinctly stated his concern with the lack of rationale by noting:

The quantitative components of the Standards tend to be useful for political leverage only as long as no one inquires into them too closely. If anyone asks the basis for any quantitative standard, one is usually at a loss to reply. I am not aware of anything ever published to explain the basis of any of the numerical formulas. I urge your Committee to undertake to "make public" in some fashion the rationale for each such standard. There are, of course, risks in such exposure, but in the long run it will enhance the credibility of the Standards and of those who appeal to them. ${ }^{10}$

The current Standards Committee will be challenged to develop objective rationale for any quantitative measures they use. David Kaser also noted this weakness and spoke to the need for doing more research in developing the standard. He stated:

Research findings, of course, which can substitute sure and certain knowledge for opinion, belief and faith, should provide the proper foundations for quantitative standards. The advent over the last couple of decades, slow though it may have been, of more sophisticated and powerful research methodologies onto the library scene augurs well for future standardsmakers. Optimizing and regression techniques, modeling, input/output analyses, and other research processes utilizing the capabilities of the computer, all promise better and more tenable standards in the years ahead."

\section{Counting Audiovisual and Microforms}

The attempt to give credit to recognize audiovisual materials and microforms as an integral part of the library collection has resulted in making the collections formula less challenging. As noted 
previously, by counting these types of materials, two-thirds of the institutions surveyed have Grade A collections. More than 70 percent found the formula to range from adequate to too low. While microforms and audiovisual materials need to be recognized, it would appear that an adjustment in the formula is needed. Furthermore, technological developments that make full-text access available online have the potential for impacting collection size.

\section{The "Richness" of the Staffing Formula}

The survey showed that as many as 66 percent of academic libraries are understaffed, according to Formula B. How are these libraries coping? Is there a substantial difference in the level of basic services being offered between libraries that are well endowed with staff and those that are not as richly blessed? Soon after the 1986 standards were published, two articles appeared that analyzed the staffing formula with the actual staffing levels in two statewide systems. Phillip M. White found that of the nineteen libraries in the California State University system, only 68 percent had what Formula B called for, only one fell into the Grade A category, and fourteen were graded C or lower. ${ }^{12}$ Ronnie W. Faulkner also compared the West Virginia Public Colleges against Formula C. He found that those institutions had 66 percent of the number of librarians called for and 52 percent of the recommended support staff. He concluded that "the formula for staffing seems excessively liberal," and that "while there seems to be no doubt that the college libraries are understaffed, little is to be gained by arguing that the situation is worse than it is in reality." ${ }^{13}$ The analysis of library staffing in these two statewide systems suggests that Formula B and the two-to-one ratio may require a more thorough review and accompanying rationale.

\section{Additional Areas for Standards Development}

Respondents to the survey indicated that standards relating to database access and resource sharing would be useful. There appears to be additional interest in incorporating standards that would address audiovisual issues more directly. Although reference to, and consideration of, audiovisual matters was given in Standards 2 (collections), Standards 6 (facilities), and Standards 8 (budget), there still appears to be the need for greater and more precise focus in this area.

\section{CONCLUSION}

The survey of libraries regarding the 1986 College Library Standards indicated that they are of value and are being used. Their quantitative nature continues to appeal to the vast majority of those who use them. Yet, the survey suggests a need for revision, which is something that goes beyond mere editing. As the College Libraries Standards Committee assumes its task, it should be aware of the challenge others have faced in developing and revising standards. The venerable Robert B. Downs stated in his Report of the Committee on University Library Standards to the Association of Research Libraries in January 1975:

Several years ago when Stephen McCarthy called me to ask if I would serve as Chairman of the Joint Committee (ARL/ACRL), I thought that it was an excellent idea and I accepted without hesitation. I thought that standards have been a useful tool in college libraries and various other types of libraries, so why not for university libraries? My innocence and naiveté soon came in for several rude shocks. ${ }^{14}$

While Downs did not elaborate on the "rude shocks" encountered, similar sentiment was later echoed by David Kaser, who served on the ACRLad hoc committee to revise the 1959 Standards. He noted:

Much of the persistent frustration at the academic library community's inability to fashion tenable standards for itself can probably be attributed to the fact that it looks so deceptively easy. Like defining "pornography," the unwary falls easily into the trap of assuming that, given a little time and motivation, any modestly informed person could do it. Many knowledgeable librarians have tried unsuccessfully to make standards, however, and the 
very high failure rate among these efforts bespeaks clearly the formidable character of the task. ${ }^{15}$

While the difficulties of making the standards effective, timely, and mean- ingful are clearly articulated by Downs and Kaser, it is a task worthy of the challenge and one that will continue to benefit the profession and the college libraries that they serve.

\section{REFERENCES AND NOTES}

1. Association of College and Research Libraries, College Library Standards Committee, "Standards for College Libraries," College \& Research Libraries News 47(Mar. 1986): 189.

2. Ibid.

3. Ibid., 199.

4. Carnegie Comprehensive and Liberal Arts Type I and II institutions are described as follows:

Comprehensive Universities and Colleges I. These institutions offer baccalaureate programs and, with few exceptions, graduate education through the master's degree. More than half of their baccalaureate degrees are awarded in two or more occupational or professional disciplines, such as engineering or business administration. All of the institutions in this group enroll at least 2,500 students.

Comprehensive Universities and Colleges II. These institutions award more than half of their baccalaureate degrees in two or more occupational or professional disciplines, such as engineering or business administration, and many also offer graduate education through the master's degree. All of the colleges and universities in this group enroll between 1,500 and 2,500 students.

Liberal Arts College I. These highly selective institutions are primarily undergraduate colleges that award more than half of their baccalaureate degrees in arts and science fields.

Liberal Arts College II. These institutions are primarily undergraduate colleges that are less selective and award more than half of their degrees in liberal arts fields. This category also includes a group of colleges that award less than half of their degrees in liberal arts but, with fewer than 1,500 students, are too small to be considered comprehensive.

5. Larry Hardesty and Stella Bentley, "The Use and Effectiveness of the 1975 'Standards for College Libraries': A Survey of College Library Directors," in Options for the '80s, Association of College and Research Libraries, Second National Conference, 1981.

6. David B. Walch, "Academic Libraries and Campus Computing Organizations: Relationships after the First Century," in Building on the First Century, Association of College and Research Libraries, Fifth National Conference, 1989.

7. Association of College and Research Libraries, "Standards for College Libraries," 193.

8. Ibid., 195.

9. Association of College and Research Libraries, University Library Standards Committee. "Standards for University Libraries: Evaluation of Performance," College and Research Libraries News 50(Sept. 1989):679

10. Correspondence to Jacquelyn McCoy, Chair of the Ad Hoc College Library Standards Committee, from Hans E. Bynagle, Library Director of Whitworth College, Spokane, Wash. May 20, 1985.

11. David Kaser, "Standards for College Libraries," Library Trends 31(Summer 1982): 17.

12. Phillip M. White, "College Library Formulas Applied," College \& Research Libraries News 46(Summer 1986): 202.

13. Ronnie W. Faulkner, "West Virginia Public Colleges and the Latest ACRL Standards," West Virginia Libraries 39(Summer 1986): 32.

14. Association of Research Libraries, "Minutes of the Eighty-Fifth Meeting," Jan. 18, 1975, 69.

15. Kaser, "Standards for College Libraries," 7. 